\title{
Comparative testing of different methods for evaluation of Varroa destructor infestation of honey bee colonies
}

\begin{abstract}
Different methods for evaluation of the degree of Varroa destructor infestation of honey bee colonies were tested. The methods using in vivo evaluation were the most sparing for the bees but less precise. The methods using evaluation with the killing of the bees or brood were the most precise but less sparing for bees.

Riassunto - Test comparativi su diversi metodi per la valutazione dell'infestazione di Varroa destructor in colonie d'api

Sono stati testati diversi metodi per valutare il grado di infestazione da Varroa destructor in colonie di api. I metodi che utilizzano la valutazione in vivo, preservano le api, ma si sono rivelati meno precisi. I metodi più invasivi, che prevedono l'uccisione di api adulte o covata, sono risultati i più precisi.
\end{abstract}

Key words: Infestation, evaluation, precise, destructive or sparing methods.

\section{INTRODUCTION}

Among the parasites infesting A. mellifera the varroa mite, Varroa destructor Anderson \& Trueman, is considered the most serious one (Bailey and Ball, 1991). It have become for two decades now the scourge of Italian and European beekeepers with losses of numerous colonies of bees annually. Studies on the biology of the mite, testing of new formulations for its control increases from year to year, along with the search of suitable and precise methods of evaluation of varroa infestation.

There are several methods to determine the rate of varroa infestation in bee colonies.

The most widely used methods include the following.

Evaluation of natural mite mortality with the use of a hive bottom drawer covered with adhesive substances retaining varroa mites falling from the body of bees. However, according to Branco et al. (2006), this method can be considered reliable only if there is an adequate amount of brood, and if the infestation is in the early stages. Close to the above method is the analysis of the debris collected from the bottom of the hive for the presence of the fallen varroa mites (Calatayud and Verdu, 1993). However, this method is efficient only at low-level infestation (Fries et al., 1991). 
Evaluation of the mite infestation by sampling of adult bees taken from the hive and exposed to treatment by different ways: washing with different liquids and detergents (De Jong et al., 1982), rotating in a jar with little amount of ether (Shabanov et al., 1980; Ellis et al., 1988) to separate and count the mites. However, the latter procedure can show overrated values in a survey with higher infestation levels and is unsafe because of the high flammability of ether vapors (Fakhimzadeh, 2001).

Evaluation by sampling the preimaginal bee stages (larvae and pupae of workers and drones) taken from newly capped brood combs and examined for the presence of mites in cells (De Jong, 1979; Szabo, 1989). Brood examination, according to Herbert et al. (1989), is a protracted laborious procedure and can be implemented only when the brood is available.

Evaluation by using of toxic vapor chemicals placed in a hive to stimulate falling of mites (Ellis et al., 1988). However, there are some evidences that chemicals can contaminate honey (Atienza et al. 1993) and other products of hive (Chauzat and Faucon, 2007).

Some authors have published analytical works on comparison of different methods of evaluation of the mite infestation in a hive, but with different conclusions (Herbert et al., 1989; Garza and Wilson, 1994; Branco et al., 2006; Barlow and Fell, 2009).

Therefore, the evaluation and development of different diagnostic methods of Varroa destructor to find the most precise, suitable and sparing ones is vital for successful integrated pest management strategy of the mite control.

\section{MATERIALS AND METHODS}

Testing of different methods to value the degree of infestation was carried out on the basis of calculating the number of female mites per 100 adult bees and the percentage of cells with worker bee or drone brood affected by the mite.

The experiments were carried out in isolated apiary. The hives were placed so that drifting of foragers was reduced. Availability of nectar sources was sufficient. Colonies were not remarkably affected by diseases other than varroasis.

The colonies were inspected to note their conditions and the presence of the queen at the beginning and at the end of the experiment.

The following four methods were tested in the same four experimental colonies selected from colonies of the apiary. In every colony all four methods were tested to get the reliable average value. Experimental colonies were selected of approximately equal average strength of bees and brood.

\section{Vivo evaluation}

METHOD 1. Examination of adults. About 100 adult bees from the middle comb frame of the hive were collected using the exhauster and placed in the diagnostic device (a box $150 \times 150 \mathrm{~mm}$ made of transparent plastic with a hinged lid and side walls having the interior height of $4 \mathrm{~mm}$ ). In the closed box the bees were pressed by the lid and fixed in a stationary position. Then bees were inspected and the counts the number of bees 
themselves, as well as mites on their body were made. The number of detected mites was divided by the number of bees in the box and multiplied by 100 to get the number of mites per 100 bees. After counts the bees were released back into their colony. This procedure was replicated 4 times to get the reliable average value.

METHOD 2. Examination of the brood. The newly constructed comb with the bee or drone brood before capping was taken and the square of $50 \times 50 \mathrm{~mm}$ (containing approximately 100 worker bee or 80 drone cells) was viewed through a strong light source. Counts of number of mites were made, and calculated per 100 cells. The procedure was replicated 4 times to get the reliable average value.

\section{Evaluation with the killing of bees or brood}

METHOD 3.Approximately 100 bees were taken from a mid comb of a colony and shaken off in a bright tray filled with hot $\left(+70 \ldots 90^{\circ} \mathrm{C}\right) 1 \%$ water solution of soda, vigorously stirred for 3-5 minutes. The mites fallen from the bees were counted to get the number of mites per 100 bees. METHOD 4. To detect mites in a brood, 100 cells with a bee or drone brood from a mid combs on the border of the upper and the middle third closer to the hive entrance were uncapped. The cell and larva/pupa taken by tweezers were examined for the presence of mites and the calculation of a percentage of cell infestation was made.

Both procedures were replicated 4 times to get the reliable average value.

\section{RESULTS AND DISCUSSION}

\section{Vivo evaluation}

METHOD 1. The testing of adult bees placed in the diagnostic device showed the following results (table 1).

Table 1 - Average rate of varroa infestation (\%) in experimental colonies, evaluated by method 1.

\begin{tabular}{|c|c|c|c|}
\hline $\begin{array}{c}\text { Number of } \\
\text { the colony }\end{array}$ & $\begin{array}{c}\text { Average number of } \\
\text { bees per device }\end{array}$ & $\begin{array}{c}\text { Average number of } \\
\text { mites } \\
\text { per device }\end{array}$ & $\begin{array}{c}\text { Average rate of } \\
\text { infestation, \% }\end{array}$ \\
\hline 1. & 96.5 & 3.0 & 3.1 \\
2. & 102.3 & 2.5 & 2.5 \\
3. & 106.5 & 3.5 & 3.3 \\
4. & 98.0 & 1.8 & 1.8 \\
\hline Average & 100.8 & 2.7 & 2.7 \\
\hline
\end{tabular}

As seen from the table 1, the average rate of varroa infestation in experimental colonies evaluated by method 1 was $2.7 \%$.

\section{Advantages of the method:}

The diagnosis is carried out on adult bees and therefore can be implemented at any time of a season. The bees fixed in the device are able to move their legs, but cannot 
move. It contributed to careful counting of bees and mites, and more precise evaluation of the degree of infestation. After counts the bees can be returned back into their colony.

\section{Disadvantages of the method:}

Diagnosis of the varroasis is complicated by the fact that mites are afraid of daylight and try to hide between the segments of bees. In addition, mites have a gray-yellow color, which not always lets to notice them.

METHOD 2. Vivo diagnosis was carried out on the worker bee brood before capping. The results of counting mites by viewing the $50 \times 50 \mathrm{~mm}$ square of comb through the strong sun light are presented in the table 2 .

Table 2 - Average rate of varroa infestation (\%) in experimental colonies, evaluated by method 2.

\begin{tabular}{|c|c|c|c|}
\hline $\begin{array}{c}\text { Number of } \\
\text { the colony }\end{array}$ & $\begin{array}{c}\text { Average number of } \\
\text { immature bees per } \\
\mathbf{5 0} \times \mathbf{5 0} \mathbf{~} \mathbf{m} \text { square of } \\
\mathbf{c o m b}\end{array}$ & $\begin{array}{c}\text { Average number of } \\
\text { mites } \\
\text { per } \mathbf{5 0} \times \mathbf{5 0} \mathbf{~ m m} \\
\text { square of comb }\end{array}$ & $\begin{array}{c}\text { Average rate of } \\
\text { infestation, \% }\end{array}$ \\
\hline 1. & 100.8 & 4.5 & 4.5 \\
2. & 82.0 & 3.8 & 4.6 \\
3. & 96.3 & 5.0 & 5.2 \\
4. & 85.8 & 2.3 & 2.7 \\
\hline Average & 91.2 & 3.8 & 4.2 \\
\hline
\end{tabular}

As seen from the table 2, the average rate of varroa infestation in experimental colonies evaluated by method 2 was $4.2 \%$. It would seem that this method is more precise than method 1, because it gives higher values of infestation of the same colonies.

However, the average ratio of infestation of worker bee brood and adult bees in late summer/beginning of autumn is usually about $2: 1$. If we compare the average rate of infestation of immature bees evaluated by method $2(4.2 \%)$ with the average rate of infestation of adult bees evaluated by method $1(2.7 \%)$, the ratio of infestation of brood and adult bees will only be 1.55: 1 . This means that not all the mites in samples were seen and fell into account.

\section{Advantages of the method:}

The method does not demand special devices. The diagnosis is carried out on brood before capping, thus keeping bees alive.

\section{Disadvantages of the method:}

The diagnosis is carried out on bee brood and therefore it cannot be implemented at any time of a season. The method demands the acute eyesight of the viewer. The method is not too accurate.

Thus, method 2 can be used for the evaluation of rate of varroa infestation of bee colonies only to a limited extent. 


\section{Evaluation with the killing of bees or brood}

METHOD 3. The testing of adult bees placed in plastic trays filled with hot $1 \%$ water solution of soda was conducted on the same specimens, which were used for testing by method 1 .

The results are presented in the table 3 .

As it is seen in the table 3 , the average rate of varroa infestation in experimental colonies evaluated by method 3 was $3.5 \%$.

The comparison of the average rate of infestation of bees evaluated by method 1 (2.7\%) with the average rate of infestation of the same specimens of bees evaluated by method 3 (3.5\%) shows that method 3 is 1.3 times more precise than method 1. It is obvious that not all the mites in the samples can be seen when bees are tested by method 1 and significant amount of mites escapes from counts when testing bees by this method.

Table 3 - Average rate of varroa infestation (\%) in experimental colonies, evaluated by method 3.

\begin{tabular}{|c|c|c|c|}
\hline $\begin{array}{c}\text { Number of } \\
\text { the colony }\end{array}$ & $\begin{array}{c}\text { Average number of } \\
\text { bees per tray }\end{array}$ & $\begin{array}{c}\text { Average number of } \\
\text { mites per tray }\end{array}$ & $\begin{array}{c}\text { Average rate of } \\
\text { infestation, } \%\end{array}$ \\
\hline 1. & 96.5 & 3.3 & 3.1 \\
2. & 102.3 & 4.5 & 4.4 \\
3. & 106.5 & 3.8 & 3.6 \\
4. & 98.0 & 2.8 & 2.9 \\
\hline Average & 100.8 & 3.6 & 3.5 \\
\hline
\end{tabular}

Thus, method 3 is more precise than method 1 , because it makes possible to distinguish higher values of Varroa infestation.

\section{Advantages of the method:}

The diagnosis is carried out on adult bees and therefore can be implemented at any time of a season. The method does not demand complicated devices and can be carried out in field conditions with any suitable tray. The method does not require expensive chemicals. The method is more accurate.

\section{Disadvantages of the method:}

The main disadvantage of the method is that it is a destructive one because of killing of captured bees during the evaluation process. The using of plastic trays did not let to use boiling water which kills bees quickly and makes mites to fall on bottom immediately. Therefore, it is better to use glass containers.

METHOD 4. The evaluation of bee brood infestation by the mite was carried out on the worker bee brood. The results of the cell and taken brood examination for the presence of mites are presented in the table 4.

As seen from the table 4 , the average rate of varroa infestation in experimental colonies evaluated by method 4 was $6.8 \%$. This figure should be considered as a true 
rate of varroa infestation of the brood in experimental colonies, because these data were obtained by the direct counting of mites on the brood. This method proved to be the most precise of all other methods, because it gives the highest values of infestation of the same colonies.

Table 4 - Average rate of varroa infestation (\%) in experimental colonies, evaluated by method 4.

\begin{tabular}{|c|c|c|c|}
\hline $\begin{array}{c}\text { Number of } \\
\text { the colony }\end{array}$ & $\begin{array}{c}\text { Number of immature } \\
\text { bees per sample }\end{array}$ & $\begin{array}{c}\text { Average number of } \\
\text { mites } \\
\text { per sample }\end{array}$ & $\begin{array}{c}\text { Average rate of } \\
\text { infestation, \% }\end{array}$ \\
\hline 1. & 100.0 & 6.5 & 6.5 \\
2. & 100.0 & 5.8 & 5.8 \\
3. & 100.0 & 6.3 & 6.3 \\
4. & 100.0 & 8.5 & 8.5 \\
\hline Average & 100.0 & 6.8 & 6.8 \\
\hline
\end{tabular}

In addition, the average ratio of infestation of worker bee brood and adult bees in late summer/beginning of autumn is usually about $2: 1$. If we compare the average rate of infestation of immature bees evaluated by method $4(6.8 \%)$ with the average rate of infestation of adult bees evaluated by method $3(3.5 \%)$, the ratio of infestation of brood and adult bees will be $1.9: 1$, which is very close to the mentioned above theoretical ratio - 2:1

\section{Advantages of the method:}

The method is the most precise because it makes possible the direct counting of mites on bees. All mites are confined in cells, what contributes to more careful counting of mites and therefore more precise evaluation of the rate of infestation. The method does not require special devices and can be carried out in field conditions.

\section{Disadvantages of the method:}

The shortcomings of the method are the continuation of its merits. The main disadvantage of the method is that it is a destructive one because of killing of opened immature bees during the evaluation process. The method is labor consuming. The diagnosis is carried out on a bee brood and therefore it cannot be implemented at any time of a season.

The comparison of the significance of average rates of varroa infestation (\%) in experimental colonies, evaluated by different methods using t-criterion of Student (table 5) showed that difference between the averages obtained by methods 1 and 2 was significant at $\mathrm{P}<0.01$; between methods 1 and $4 ; 3$ and 4 were significant at $\mathrm{P}<0.05$. The differences between the averages obtained by methods 1 and $3 ; 2$ and 3;2 and 4 were non significant. 
Table 5 - The comparison of the significance of average rates of varroa infestation (\%) in experimental colonies, evaluated by different methods.

\begin{tabular}{|c|c|c|c|c|c|c|c|c|c|}
\hline \multicolumn{7}{|c|}{ The comparison of the significance of differences between the averages obtained by different } \\
methods using t-criterion of Student
\end{tabular}

\section{PRELIMINARY CONCLUSIONS}

1. All tested methods of the evaluation of a rate of varroa infestation of bee colonies have their aadvantages and disadvantages. The methods using vivo evaluation are the most sparing for bees but less precise. The methods using evaluation with the killing of bees or brood are the most precise but less sparing for bees.

2. The methods 1 and 2 are not too precise, because not all the mites in the samples can be noticed when testing bees by these methods, though method 2 is more precise than method 1 .

3. Method 3 is 1.3 times more precise than method 1 , because it lets to distinguish higher values of varroa infestation.

4. The most precise is method 4 , because it gives the opportunity of direct counting of mites on bees. However, the method is the most destructive because of killing of opened immature bees during the evaluation.

5 . The difference between the average rates of varroa infestation obtained by methods 1 and 2 was significant at $\mathrm{P}<0.01 ; 1$ and $4 ; 3$ and 4 were significant at $\mathrm{P}<0.05$. The differences between the averages obtained by methods 1 and 3;2 and 3;2 and 4 were non significant.

6. Therefore it is necessary to continue the present research to develop the formula of the most precise extrapolation of the data obtained by vivo diagnosis to real degree of infestation.

\section{ACKNOWLEDGMENTS}

Work supported with a grant of Lombardy Region (Italy). Research project: "Varroa destructor control strategy and monitoring of Nosema ceranae and N. apis diffusion in Lombardy" STRANOVA. 


\section{REFERENCES}

Atienza J., Jimenez J. J., Bernal J. L., Martin M. T., 1993 - Supercritical fluid extraction of fluvalinate residues in honey. Determination by high-performance liquid chromatography. Journal of Chromatography, Biomedical Applications, 655: 95-99.

Bailey L., Ball B., 1991 - Honey bee pathology. Academy Press London, pp 193.

BARLOW V. M., FELL D. R., 2009 - Sampling methods for Varroa mites on the domesticated honeybee. Virginia State University, 444-103.

BRANCO M . R., KidD N.A.C., PICKARD R., 2006 - A comparative evaluation of sampling methods for Varroa destructor (Acari: Varroidae) population estimation, Apidologie 37: 452-461

CAlatAYUd F., Verdu M.J., 1993 - Hive debris counts in honeybee colonies: a method to estimate the size of small populations and rate of growth of the mite Varroa jacobsoni Oud. (Mesostigmata: Varroidae), Exp. Appl. Acarol. 17: 889-894.

Chauzat M.P., FAucon J.P., 2007 - Pesticide residues in beeswax samples collected from honey bee colonies (Apis mellifera L.) in France. Pest Manag Sci, 63: 1100-1106.

DE Jong D., 1979 - Field identification of Varroa jacobsoni, a parasitic mite of honey bees.- Gleaning in Bee Cult., 107: 639-640, 644.

De Jong D., De Andrea Roma D., Goncalves L.S., 1982 - Comparative analysis of shaking solutions for the detection of Varroa jacobsoni on adult honeybees, Apidologie 13, 297-303.

Ellis M., Nelson R., Simonds C., 1988 - A comparison of the fluvalinate and Ether roll methods of sampling for Varroa mites in honey bee colonies. - Amer. Bee J., 128: 262-263.

FAKHIMZADEH K., 2001 - Detection of major mite pests of Apis mellifera and development of nonchemical control of varroasis. Academic dissertation. University of Helsinki Department of Applied Biology publication no. 3. Helsinki: 46 pp.

Fries I., Aarhus A., Hansen H., Korpela S., 1991 - Comparison of diagnostic methods for detection of low infestation levels of Varroa jacobsoni in honey-bee (Apis mellifera) colonies. Exp. Appl. Acarol., 10: 279-287.

GARZA Q.C., WILSON W.T., 1994 - Different sampling methods for assessment of Varroa jacobsoni infestations, Am. Bee J.: 134, 832.

Herbert E. W., Witherell P. C., Bruce W. A., Shimanuki H., 1989 - Evaluation of six methods of detecting Varroa mites in beehives, including the experimental use of acaricidal smokes containing fluvalinate or amitraz. Amer. Bee J., 129: 605-608.

Shabanov M., Nedjalkov S., Toshrov A. L., 1980 - Eine Schnelle einfache Methode zur Varroatose-Diagnose. In: Diagnose und Therapie der Varroatose - Apimondia Publishing House, Bucharest, Romania: 108.

SzABo T. I., 1989 - The capping scratcher: A tool for detection and control of Varroa jacobsoni. Amer. Bee J., 129: 402-403.

NiKolay D. Dobrynin - Department of Plant Protection, Voronezh State Agricultural University, 1 Michurina st., Voronezh, 394087, Russia, E-mail: ndobrynin@rambler.ru

Mario Colombo, Francesca Romana Eördegh - Dipartimento di Protezione dei Sistemi Agroalimentare e Urbano e valorizzazione delle Biodiversità- DiPSA, Università degli Studi di Milano,Via Celoria 2, 20133 Milano - Italy. E-mail: mario.colombo@unimi.it

Accepted 6 October 2011 